\title{
PENGGUNAAN MEDIA KARTU BERGAMBAR UNTUK MENINGKATKAN KEMAMPUAN MEMBACA SISWA KELAS II SDN 067 PEKANBARU
}

\author{
Eka Ramadhan Sari, Otang Kurniaman \\ ekaramadhansari309@gmail.com, kurniaman_otang@yahoo.com \\ Program Studi Pendidikan Guru Sekolah Dasar \\ Universitas Riau, Indonesia
}

Abstract: This research is motivated by the low reading ability of 2 nd grade students at SDN 067 Pekanbaru. The low reading ability of students is caused by the teacher not using learning media in learning so that the learning process becomes monotonous and students' abilities are different. One of the media that can be used to improve reading skills is the flashcard media. Media flashcard is a method of reading by using a card that contains pictures that are equipped with words. This study aims to improve the reading skills of 2nd grade students at SDN 067 Pekanbaru the use of flashcard. The research conducted was classroom action research with research subjects namely students in class 2 SDN 067 Pekanbaru totaling 24 people. The results of research on teacher activity increased at the first meeting of the cycle I with a presentation of $70.83 \%$, at the second meeting increased to $75 \%$. Then in the cycle II increased again at the first meeting $83.33 \%$, and the second meeting increased to $87.5 \%$. Meanwhile student activity also increased, namely at the first meeting of the cycle I having a percentage of $70.83 \%$ at the second meeting to $79.17 \%$. Then at the first meeting the cycle I increased to $87.5 \%$, at the second meeting increased again to $91.67 \%$. The results of

Submitted:

12 Juli 2019

$12^{\text {th }}$ July 2019 increasing the reading ability of 2nd grade students at SDN 067 Pekanbaru, from the base score of 63.75 , increased in the cycle I to 73.88 with a percentage of $15.89 \%$, then in the cycle I again increased to 83.96 with a percentage of $31.70 \%$.

Accepted:

17 September 2019

$17^{\text {th }}$ September 2019

\section{Keywords: flashcard, reading ability}

Abstrak: Penelitian ini dilatarbelakangi oleh rendahnya kemampuan membaca siswa kelas II SDN 067 Pekanbaru. Rendahnya kemampuan membaca siswa disebabkan karena guru tidak menggunakan media belajar dalam pembelajaran sehingga proses belajar menjadi monoton serta kemampuan siswa yang berbeda-beda. Salah satu media yang dapat digunakan untuk meningkatkan kemampuan membaca yaitu media kartu bergambar. Media kartu bergambar adalah suatu metode membaca dengan menggunakan kartu yang berisikan gambar yang dilengkapi oleh kata-kata. Penelitian ini bertujuan untuk meningkatkan kemampuan membaca siswa kelas II SDN 067 Pekanbaru penggunaan kartu bergambar. Penelitian yang dilakukan adalah penelitian tindakan kelas dengan subjek penelitian yaitu siswa kelas II SDN 067 Pekanbaru berjumlah 24 orang. Hasil penelitian aktivitas guru mengalami peningkatan pada pertemuan pertama siklus I dengan presentasi 70,83\%, pada pertemuan kedua meningkat menjadi $75 \%$. Kemudian pada siklus II mengalami peningkatan kembali pada pertemuan pertama $83,33 \%$, dan pertemuan kedua maningkat menjadi $87,5 \%$. Sementara itu aktivitas siswa juga mengalami peningkatan yaitu pada pertemuan pertama siklus I memiliki persentasi $70,83 \%$ pada pertemuan kedua menjadi 79,17\%. Kemudian pada pertemuan pertama siklus II meningkat menjadi 87,5\%, pada pertemuan kedua meningkat kembali menjadi 91,67\%. Hasil peningkatan kemampuan membaca siswa kelas II SDN 067 Pekanbaru yaitu dari skor dasar 63,75 meningkat pada siklus I menjadi 73,88 dengan persentase 15,89\%, kemudian pada siklus II kembali mengalami peningkatan menjadi 83,96 dengan persentase $31,70 \%$.

Kata Kunci: kartu bergambar, kemampuan membaca

\section{CITATION}

Sari, E.S., \& Kurniaman, O. (2019). Penggunaan Media Kartu Bergambar untuk Meningkatkan Kemampuan Membaca Siswa Kelas II SDN 067 Pekanbaru. Primary: Jurnal Pendidikan Guru Sekolah Dasar, 8 (2), 125-138. DOI: http://dx.doi.org/10.33578/jpfkip.v8i2.7628. 


\section{PRIMARY : JURNAL PENDIDIKAN GURU SEKOLAH DASAR \\ Volume 8 Nomor 2 Oktober 2019 \\ DOI : http://dx.doi.org/10.33578/jpfkip.v8i1.7628 \\ ISSN : 2303-1514 | E-ISSN : 2598-5949 \\ https://primary.ejournal.unri.ac.id/index.php/JPFKIP}

\section{PENDAHULUAN}

Pelajaran bahasa Indonesia merupakan salah satu mata pelajaran wajib yang diajarkan di $\mathrm{SD}$, karena bahasa Indonesia mempunyai kedudukan dan fungsi yang sangat penting dalam kehidupan sehari-hari. Saat ini mata pelajaran bahasa Indonesia telah mencangkup seluruh aspek kebahasaan yaitu menyimak, berbicara, membaca, dan menulis. Kemampuan membaca selalu ada pada setiap tema pembelajaran. Hal itu membuktikan bahwa membaca merupakan suatu kemampuan yang sangat penting. Dalam proses belajar mengajar di sekolah secara umum membaca dibagi menjadi dua tahap yaitu membaca permulaan dan membaca lanjutan. Membaca permulaan merupakan tahap awal dalam belajar membaca yang difokuskan pada pengenalan simbol-simbol atau tanda-tanda yang berkaitan dengan huruf-huruf sehingga menjadi pondasi agar siswa dapat melanjutkan ketahap membaca lanjut. Meskipun demikian kemandirian siswa dalam membaca permulaan belum bisa dilepaskan sepenuhnya saat membaca kata atau kalimat. Pada tahap ini siswa sangat membutuhkan bimbingan dari guru atau orang tua. Membaca permulaan memegang peranan penting yang mendukung tahap membaca lanjut.

Sesuai dengan pendapat Sismulyasih (2018) jika pembelajaran literasi (membaca dan menulis) di kelas awal tidak kuat, maka pada tahap membaca dan menulis lanjut siswa akan mengalami kesulitan untuk dapat memiliki kemampuan membaca dan menulis yang memadai. Zuchdi dan Budiasih (Sismulyasih, 2018) mengungkapkan bahwa kemampuan membaca yang diperoleh pada membaca permulaan akan sangat berpengaruh terhadap kemampuan membaca tingkat lanjut.

Menurut Solchan (2014) kemampuan membaca lebih diorientasikan pada kemampuan membaca tingkat dasar, yakni kemampuan merek huruf maksudnya, anak-anak dapat mengubah dan menghafalkan lambang-lambang tertulis menjadi bunyi-bunyi bermakna. Pada tahap ini sangat memungkinkan anak-anak dapat melafalkan lambang-lambang huruf yang dibacanya tanpa diikuti oleh pemahaman terhadap lambanglambang bunyi tersebut. Selanjutnya dilanjutkan dengan kemampuan membaca tingkat lanjut yakni melek wacana maksudnya kemampuan membaca sesungguhnya, yakni kemampuan mengubah lambang-lambang tulis menjadi bunyi-bunyi bermakna disertai pemahaman akan lambanglambang tersebut. Hal ini sejalan dengan pendapat Nugraheni (2012) mengatakan membaca permulaan sebatas mengeja atau melafalkan huruf, suku kata, kata, kalimat sederhana. Membaca jenis ini yang penting anak bisa membaca secara sadar tanpa kesalahan, cukup jelas dan fasih.

Progress in internasional reading literacy study (PIRLS) yaitu studi internasional dalam bidang membaca pada anak-anak di seluruh dunia pada tahun 2009, menunjukkan bahwa rata-rata anak Indonesia berada pada urutan keempat dari bawah dari 45 negara di dunia. Hasil studi tersebut dipaparkan oleh Prof. Dr. Suhardjono dari Pusat Penelitian Pendidikan Depdiknas. Suhardjono menuturkan, muara dari lemahnya pembelajaran membaca diduga karena kemampuan guru dan kondisi sekolah. Kemampuan guru yang dimaksud yaitu keterampilan dalam mengajar dan menerapkan metode mengajar dan strategi mengajar (Aryani, 2012). Pendapat tersebut juga didukung oleh Hermida (2009) in the past decades researchers discovered a mutual relationship between a student's academic reading skills and academic success. Students as well as teachers, however, take the learning of this skill for granted. As a result, most students use a surface approach to reading in reading academic reading materials.

Berdasarkan observasi yang dilakukan dikelas II SDN 067 Pekanbaru dari 24 siswa hanya 13 siswa $(54,17 \%)$ baik dalam membaca, dan 11 siswa $(45,83 \%)$ kurang baik dalam membaca. Hal ini disebabkan oleh: (1) proses belajar yang selalu monoton; (2) kurang melakukan latihan membaca; (3) kemampuan siswa yang berbeda-beda; (4) kurangnya motivasi siswa untuk belajar; (5) guru yang mengajar tidak menggunakan media belajar. Irdawati (2016) juga mengungkapkan masalahmasalah yang dihadapi oleh guru diantaranya: (1) kurangnya minat membaca siswa; (siswa kurang perhatian terhadap pembelajaran; (3) siswa yang ribut saat proses pembelajaran berlangsung; (4) siswa tidak dapat menjawab dengan maksimal.

Oleh karena itu guru harus memiliki 
kemampuan merancang berbagai strategi pembelajaran yang dianggap cocok bagi siswa, salah satunya yaitu menggunakan media pembelajaran. Dengan menggunakan media pembelajaran dapat menarik perhatian siswa dalam proses pembelajaran. Salah satu media yang dapat digunakan dalam pembelajaran bahasa Indonesia adalan media kartu bergambar.

Menurut Fadillah (2014) istilah media berasal dari kata jamak medium, yang memiliki arti perantara. Media merupakan suatu alat yang dijadikan sebagai sarana perantara untuk menyampaikan sebuah pesan, supaya pesan yang diinginkan dapat tersampaikan dengan tepat, mudah dan diterima serta dipahami sebagai mestinya. Media adalah alat bantu yang sangat bermanfaat bagi siswa dan guru dalam proses belajar mengajar. Media yang digunakan dalam proses pembelajaran sebagai penyalur pesan antaran guru dan siswa dalam proses pembelajaran agar tujuan pembelajaran tercapai. Menurut Indriana (2011) media berfungsi sebagai perantara, wadah atau penyambung pesan-pesan pembelajaran. Media berfungsi mengarahkan siswa-siswa untuk memperoleh berbagai pengalaman belajar. Menurut Kemp dan Dayton (Asyad, 2011) media pembelajaran memiliki tiga fungsi utama, yaitu: memotivasi minat atau tindakan; menyajikan informasi; memberikan instruksi.

Menurut Arsyad (2011) flashcard atau kartu bergambar adalah kartu kecil yang berisi gambar, teks, atau tanda simbol yang meningkatkan atau menuntun siswa kepada sesuatu yang berhubungan dengan gambar itu. Flashcard biasanya berukuran $8 \times 12 \mathrm{~cm}$, atau dapat

\section{METODE PENELITIAN}

Penelitian ini dilaksanakan dikelas II SDN 067 Pekanbaru. Penelitian ini dilakukan pada semester ganjil, pada bulan November tahun pelajaran 2017/2018. Subjek dalam penelitian ini adalah siswa kelas II yang berjumlah 24 siswa, yang terdiri dari 15 siswa laki-laki dan 9 siswa perempuan. Penelitian ini merupakan penelitian tindakan kelas (PTK). Menurut Mettetal (Habibi, 2017) stated that classroom action research was a method to find out which treatment worked best in disesuaikan dengan besar kecilnya kelas yang dihadapi. Indriana (2011) mengungkapkan gambar yang ditampilkan dalam kartu tersebut adalah gambaran tangan atau foto, atau gambar/foto yang sudah ada dan ditempelkan pada lembaran kartukartu tersebut.

Kelebihan kartu bergambar menurut Indriana (2011) yaitu: (1) mudah untuk dibawabawa: ukurannya yang kecil membuat kartu ini dapat disimpan di dalam tas atau saku, sehingga dapat digunakan dimana saja; (2) praktis: cara membuat dan penggunaan yang mudah serta tidak membutuhkan listrik menjadi media ini sangat praktissaat akan digunakan; (3) gampang diingat: media ini menyajikan pesan-pesan pendek yang dapat memudahkan siswa untuk mengingat pesanpesan yang disampaikan dalam proses pembelajaran; (4) menyenangkan: penggunaan media ini dapat melalui permainan sehingga proses pembelajaran akan lebih menyenangkan bagi siswa. Media kartu bergambar dapat menarik perhatian siswa dalam proses pembelajaran, dengan menggunakan media kartu bergambar sebagai media pembelajaran diharapkan minat dan motivasi siswa dalam membaca. Sehingga dapat meningkatkan kemampuan siswa dalam membaca.

Sehingga rumusan masalah dalam penelitian ini adalah "Apakah penggunaan media kartu bergambar dapat meningkatkan kemampuan membaca siswa kelas II SDN 067 Pekanbaru?". Sesuai dengan permasalahan diatas, maka tujuan penelitian ini adalah untuk meningkatkan kemampuan membaca melalui pengguanaan kartu bergambar untuk siswa kelas II SDN 067 Pekanbaru.

classroom to improve teaching and learning activities.

Pendapat ini didukung oleh Aqib (2016) penelitian tindakan kelas adalah penelitian yang dilakukan oleh guru di dalam kelasnya sendiri melalui refleksi diri, dengan tujuan untuk memperbaiki kinerjanya sebagai guru, sehingga proses pembelajaran dapat berjalan dengan baik, dan hasil belajar siswa meningkat. Hal ini sejalan dengan pendapat Hamzah (2012) yaitu: penelitian 


\section{PRIMARY : JURNAL PENDIDIKAN GURU SEKOLAH DASAR \\ Volume 8 Nomor 2 Oktober 2019 \\ DOI : http://dx.doi.org/10.33578/jpfkip.v8i1.7628 \\ ISSN : 2303-1514 | E-ISSN : 2598-5949 \\ https://primary.ejournal.unri.ac.id/index.php/JPFKIP}

tindakan kelas dapat dilakukan di dalam kelas, sehingga fokus penelitian adalah kegiatan pembelajaran berupa perilaku guru dan siswa dalam melakukan interaksi belajar mengajar. Penelitian tindakan kelas bertujuan untuk memperbaiki pembelajaran. Perbaikan dilakukan secara bertahap dan terus menerus, selama kegiatan penelitian dilakukan. Penelitian ini dilaksanakan sebanyak dua siklus. Secara garis besar, setiap siklus dilakukan melalui empat tahapan yaitu: perencanaan, pelaksanaan, pengamatan, dan refleksi.

Adapun siklus penelitian tindakan kelas digambarkan sebagai berikut:

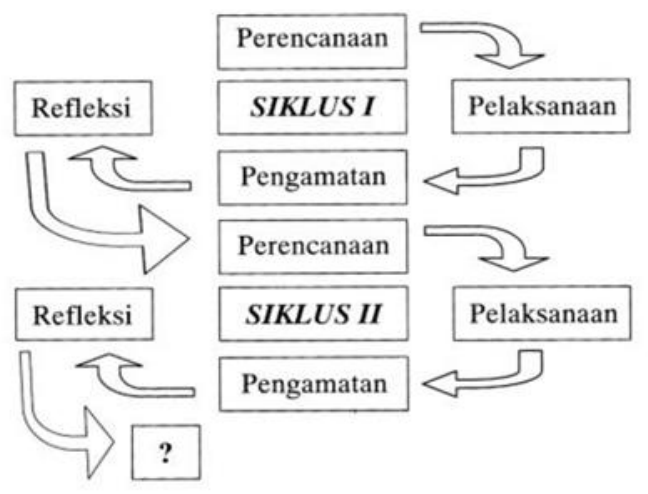

Gambar 1. Siklus Penelitian

Dalam memperoleh data penelitian, peneliti menggunakan perangkat pembelajaran dan instrumen pengumpulan data.

\section{Perangkat Pembelajaran}

\section{Silabus}

Silabus adalah rancangan pembelajaran yang berisi rencana bahan ajar mata pelajaran tertentu pada jenjang dan kelas tertentu sebagai hasil dari seleksi pengelompokkan, pengurutan, dan penyajian materi kurikulum. Silabus disusun berdasarkan prinsip yang berorientasi pada pencapaian kompetensi.

\section{Rencana Pelaksanaan Pembelajaran (RPP)}

Rencana pelaksanaan pembelajaran adalah rencana yang mengambarkan prosedur dan pengorganisasian pembelajaran untuk membantu guru dalam proses pembelajaran. RPP mencangkup: (1) data sekolah, mata pelajaran, dan kelas/semester; (2) materi pokok; (3) alokasi waktu; (4) SK, KD, indikator, tujuan pembelajaran; (5) materi pembelajaran, metode pembelajaran; (6) media, alat dan sumber belajar; (7) langkah-langkah pembelajaran; dan (8) penilaian.

\section{Lembar Kerja Siswa (LKS) \\ Lembar kerja siswa adalah lembar}

kegiatan yang berisi tugas yang biasanya berupa petunjuk atau langkah-langkah untuk menyelesaikan tugas yang harus diberikan oleh guru kepada siswa.

\section{Instrumen Pengumpulan Data}

\section{Lembar Observasi}

Lembar observasi adalah lembar yang digunakan saat pengumpulan data berupa observasi. Lembar observasi terbagi menjadi dua yaitu lembar observasi aktivitas guru dan lembar observasi aktivitas siswa. Lembar observasi aktivitas guru yang dinilai adalah kemampuan guru dalam menyampaikan pembelajaran, sedangkan lembar observasi aktivitas siswa berisi aktivitas siswa dalam melaksanakan pembelajaran.

\section{Rubik Penilaian}

Rubik penilaian merupakan penilaian yang dilakukan dengan mengamati peningkatan kemampuan membaca siswa. Rubik penilaian yang digunakan yaitu tes unjuk kerja dengan penilaian yang sesuai dengan indikator penilaian yaitu: lafal, intonasi dan kelancaran dengan skor tertinggi dalam penilaian adalah 3. Dengan rubik penilaian sebagai berikut: 


\section{PRIMARY : JURNAL PENDIDIKAN GURU SEKOLAH DASAR \\ Volume 8 Nomor 2 Oktober 2019 \\ DOI : http://dx.doi.org/10.33578/jpfkip.v8i1.7628 \\ ISSN : 2303-1514 | E-ISSN : 2598-5949 \\ https://primary.ejournal.unri.ac.id/index.php/JPFKIP}

Tabel 1. Rubik Penilaian Kemampuan Membaca

\begin{tabular}{|c|c|c|c|}
\hline No. & Aspek & Keterangan & Skor \\
\hline \multirow[t]{3}{*}{1.} & \multirow[t]{3}{*}{ Lafal } & $\begin{array}{l}\text { Jika siswa membaca seluruh teks dengan lafal yang } \\
\text { tepat. }\end{array}$ & 3 \\
\hline & & $\begin{array}{l}\text { Jika siswa membaca seluruh teks dengan lafal yang } \\
\text { kurang tepat. }\end{array}$ & 2 \\
\hline & & $\begin{array}{l}\text { Jika siswa membaca seluruh teks dengan lafal } \\
\text { yang tidak tepat. }\end{array}$ & 1 \\
\hline \multirow[t]{3}{*}{2.} & \multirow[t]{3}{*}{ Intonasi } & $\begin{array}{l}\text { Jika siswa membaca seluruh teks dengan intonasi } \\
\text { yang tepat. }\end{array}$ & 3 \\
\hline & & $\begin{array}{l}\text { Jika siswa membaca seluruh teks dengan intonasi } \\
\text { yang kurang tepat. }\end{array}$ & 2 \\
\hline & & $\begin{array}{l}\text { Jika siswa membaca seluruh teks dengan intonasi } \\
\text { yang tidak tepat. }\end{array}$ & 1 \\
\hline \multirow[t]{3}{*}{3.} & \multirow[t]{3}{*}{ Kelancaran } & Jika siswa membaca tanpa mengeja, terbata-bata. & 3 \\
\hline & & $\begin{array}{l}\text { Jika siswa membaca dengan tanpa mengeja tetapi } \\
\text { terbata-bata. }\end{array}$ & 2 \\
\hline & & $\begin{array}{l}\text { Jika siswa membaca dengan terbata-bata dan } \\
\text { memiliki banyak jeda. }\end{array}$ & 1 \\
\hline
\end{tabular}

(Adaptasi dari Zuchdi, 1997)

Teknik pengumpulan data dalam penelitian ini adalah observasi dan tes unjuk kerja. Observasi digunakan dengan mengamati aktivitas guru dan siswa dalam proses pembelajaran dengan menggunakan media kartu bergambar. Sedangkan tes unjuk kerja digunakan sebagai pengguat bahwa kemampuan membaca siswa telah mengalami peningkatan yang ditunjukkan dengan hasil tes siswa. Tes yang digunakan adalah membaca teks pendek yang terdapat pada media kartu bergambar. Teknik analisis data yang digunakan yaitu:

\section{Aktivitas Guru dan Siswa}

Penilaian aktivitas guru dan siswa dilakukan selama kegiatan belajar mengajar dengan menggunakan media kartu bergambar. Penilaian dilakukan dengan menggunakan lembar observasi penilaian aktivitas guru dan siswa. Adapun rumus yang digunakan dalam penilaian aktivitas guru dan siswa yaitu:

$\mathrm{NP}=\frac{\mathrm{R}}{\mathrm{SM}} \times 100 \% \quad($ Purwanto, 2013)

Keterangan :

$\mathrm{NP} \quad=$ nilai persen yang dicari

$\mathrm{R}=$ skor mentah yang diperoleh

$\mathrm{SM} \quad=$ skor maksimal ideal

Tabel 2. Kategori Penilaian Aktivitas Guru dan Siswa

\begin{tabular}{cc}
\hline \% Interval & Kategori \\
\hline $86-100$ & Amat baik \\
$71-85$ & Baik \\
$60-70$ & Cukup \\
$>60$ & Kurang \\
\hline
\end{tabular}

(Aqib, 2011) 


\section{PRIMARY : JURNAL PENDIDIKAN GURU SEKOLAH DASAR \\ Volume 8 Nomor 2 Oktober 2019 \\ DOI : http://dx.doi.org/10.33578/jpfkip.v8i1.7628 \\ ISSN : 2303-1514 | E-ISSN : 2598-5949 \\ https://primary.ejournal.unri.ac.id/index.php/JPFKIP}

\section{Analisis Kemampuan Membaca Siswa}

Untuk analisis data kemampuan membaca siswa secara individu dapat dihitung dengan rumus sebagai berikut:

$$
\begin{aligned}
& \mathbf{X}=\frac{\sum \mathbf{X}}{\sum \mathbf{N}} \\
& (\text { Aqib, 2016) }
\end{aligned}
$$

$\mathrm{S}=\frac{\mathrm{R}}{\mathrm{N}} \times 100 \quad$ (Purwanto, 2013)

Keterangan :

$\mathrm{X} \quad=$ Rata-rata yang dicari

Keterangan :

$\mathrm{S} \quad=$ Nilai yang diharapkan (dicari)

$\mathrm{R}=$ Jumlah skor dari item

$\mathrm{N} \quad=$ Skor maksimum

Data hasil kemampuan membaca siswa

$\sum \mathrm{X}=$ Jumlah semua nilai siswa

$\sum \mathrm{N}=$ jumlah siswa

Untuk interval dan kategori kemampuan membaca permulaan siswa dapat dilihat pada tabel berikut ini:

dicari dengan menggunakan rumus rata-rata, yaitu:

Tabel 3. Konversi Interval Penilaian Kemampuan Membaca Siswa

\begin{tabular}{ccc}
\hline No & Interval & Keterangan \\
\hline 1 & $80-100$ & Sangat Baik \\
2 & $70-79$ & Baik \\
3 & $60-69$ & Cukup \\
4 & $50-59$ & Kurang \\
5 & $0-49$ & Kurang sekali \\
\hline
\end{tabular}

Purwanto (2013)

\section{Peningkatan Kemampuan Membaca}

Peningkatan hasil keterampilan membaca yang didapatkan dari hasil tes yang telah diolah, dianalisis dengan menggunakan rumus presentase sebagai berikut:

\section{HASIL DAN PEMBAHASAN}

\section{Hasil Pelaksanaan Tindakan Siklus I Tahap Perencanaan}

Sebelum melaksanakan penelitian, peneliti telah menyiapkan perangkat pembelajaran yang disajikan dalam instrumen pengumpulan data. Perangkat pembelajaran yang diperlukan terdiri dari bahan ajar berupa: Silabus untuk seluruh kegiatan, Rencana Pelaksanaan Pembelajaran (RPP) untuk 2 kali pertemuan, Lembar Kerja Siswa (LKS) untuk 2 kali pertemuan, Soal Ulangan Harian, Lembar Kriteria Penilaian Aktivitas Guru, Lembar Obervasi Aktivitas Guru sebanyak 2 kali pertemuan, Lembar Kriteria Penilaian Aktivitas
$\mathbf{P}=\frac{\text { poserate-baserate }}{\text { baserate }} \boldsymbol{x} \mathbf{1 0 0 \%}(\mathrm{Aqib}, 2011)$

Keterangan :

$\mathrm{P} \quad=$ Presentase peningkatan

Poserate $=$ Nilai rata-rata sesudah tindakan

Baserate $=$ Nilai rata-rata sebelum tindakan

Siswa, Lembar Obeservasi Aktivitas Siswa sebanyak 2 kali pertemuan .

Tahap Pelaksanaan

Kegiatan awal

Sebelum memulai pembelajaran guru mempersiapkan kelas dengan berdoa, mengucapkan salam, dan kemudian mengabsen kehadiran siswa. Setelah itu guru melakukan appersepsi dengan mengajukan beberapa pertanyaan kepada siswa. Pernakah anak-anak membaca sebuah cerita? Cerita seperti apa yang pernah anak-anak baca?. Guru memotivasi siswa yang berkaitan dengan materi pembelajaran. 


\section{PRIMARY : JURNAL PENDIDIKAN GURU SEKOLAH DASAR \\ Volume 8 Nomor 2 Oktober 2019 \\ DOI : http://dx.doi.org/10.33578/jpfkip.v8i1.7628 \\ ISSN : 2303-1514 | E-ISSN : 2598-5949 \\ https://primary.ejournal.unri.ac.id/index.php/JPFKIP}

Selanjutnya guru menuliskan materi pembelajaran di papan tulis. Selanjutnya guru meyampaikan tujuan pembelajaran, yaitu siswa dapat membaca teks bacaan dengan lafal yang tepat dan benar. Setelah itu guru menyampaikan langkah-langkah pembelajaran yang akan dilaksanakan.

\section{Kegiatan Inti}

Pada tahap ini guru mengenalkan media kartu bergambar kepada siswa, kemudian guru menjelaskan kepada siswa cara menggunakan media kartu bergambar yang akan digunakan. Guru memberikan contoh menggunakan media kartu bergambar yaitu dengan cara mengamati gambar yang terdapat dalam kartu bergambar. Kartu bergambar yang digunakan sebagai contoh yaitu "Sakit Gigi" dalam gambar tersebut terlihat Tita yang sedang di cabut giginya oleh dokter gigi. Kemudian membaca teks bacaan yang ada dalam kartu dengan lafal yang tepat.

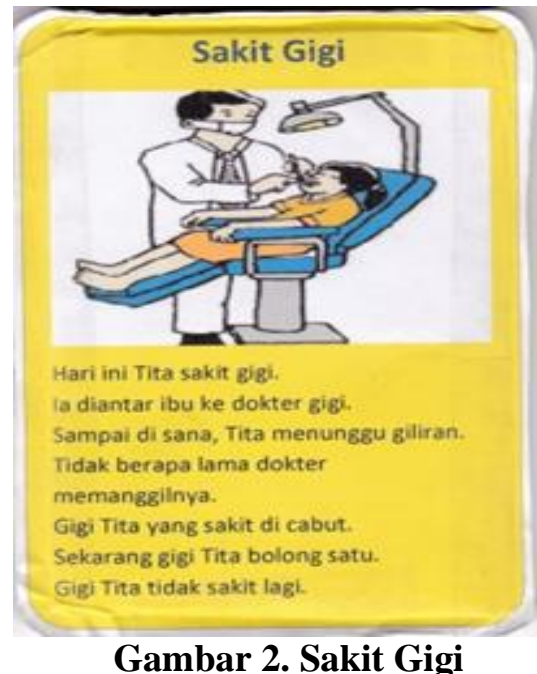

Gambar 2. Sakit Gigi

Sementara itu siswa memperhatikan guru dalam menggunakan kartu bergambar. Selanjutnya guru melakukan tanya jawab yang berkaitan dengan materi pembelajaran. Kemudian guru meminta salah satu siswa maju ke depan untuk membaca teks bacaan yang terdapat pada kartu bergambar tersebut.

Tahap Elaborasi

Setelah siswa mengetahui cara menggunakana kartu bergambar. Selanjutnya siswa dibagi oleh guru kedalam beberapa kelompok, setiap kelompok terdiri dari dua orang. Kelompok tersebut dibentuk sesuai dengan teman sebangku. Guru kemudian membagikan LKS dan kartu bergambar kepada masing-masing kelompok. Siswa memperhatikan guru dalam menjelaskan cara mengerjakan LKS yaitu dengan cara siswa diminta untuk memperhatikan kartu bergambar yang dimiliki siswa, kemudian siswa diminta untuk membaca teks yang terdapat pada kartu tersebut.
Guru membimbing siswa membaca teks bacaan yang terdapat pada kartu bergambar.

\section{Tahap Konfirmasi}

Kemudian guru meminta setiap masingmasing kelompok untuk maju ke depan kelas untuk membacakan teks bacaan yang terdapat pada kartu bergambar secara bergantian dengan lafal yang tepat. Sedangkan kelompok yang belum maju memperhatikan kelompok yang maju ke depan kelas ketika membaca kartu bergambar.

\section{Kegiatan Akhir}

Pada akhir pembelajaran guru bersama siswa membuat hasil kesimpulan pembelajaran, dan menyampaikan materi untuk pertemuan selanjutnya. Kemudian guru menutup pembelajaran dengan berdoa.

\section{Ulangan Harian Sillus I}

Ulangan Harian I ini berbentuk sebuah teks pendek sederhana. Guru meminta setiap siswa maju kedepan untuk membaca teks pendek tersebut. Guru juga melakukan penilai hasil bacaan 
siswa. Waktu yang digunakan untuk melaksanakan Ulangan Harian I ini selama 70 menit.

\section{Refleksi Siklus I}

Berdasarkan hasil pengamatan siklus I yang dilakukan sebanyak dua kali pertemuan, penggunaan media kartu bergambar ini sudah terlaksana sesuai dengan yang diharapkan. Namun masih ada kelemahan yang peneliti temukan dalam pelaksanakan penelitian, peneliti masih belum mampu mengkondisikan kelas sepenuhnya, masih banyak siswa yang ribut ketika proses pembelajaran berlangsung. Adapun upaya dilakukan pada siklus II yaitu agar peneliti lebih terampil dalam menguasai kelas, serta memotivasi siswa saat belajar agar siswa lebih semangat dalam melaksanakan proses pembelajaran

\section{Hasil Pelaksanaan Tindakan Sikuls II Tahap perencanaan}

Tahap perencanaan sebelum melaksanakan Siklus II yaitu peneliti telah menyiapkan perangkat pembelajaran yang akan disajikan dalam intrumen pengumpulan data. Perangkat pembelajaran yang diperlukan terdiri dari bahan ajar berupa : Rencana Pelaksanaan Pembelajaran (RPP) untuk 2 kali pertemuan, Lembar Kerja Siswa (LKS) untuk 2 kali pertemuan, Soal Ulangan Harian siklus II, Lembar Kriteria Penilaian Aktivitas Guru, Lembar Obervasi Aktivitas Guru sebanyak 2 kali pertemuan, Lembar Kriteria Penilaian Aktivitas Siswa, Lembar Obeservasi Aktivitas Siswa sebanyak 2 kali pertemuan.

\section{Tahap pelaksanaan}

\section{Kegiatan awal}

Sebelum memulai pembelajaran guru mempersiapkan kelas dengan berdoa, mengucapkan salam, dan kemudian mengabsen kehadiran siswa. Setelah itu guru melakukan appersepsi dengan mengajukan beberapa pertanyaan kepada siswa. Adakah diantara anakanak yang suka membaca? Coba sebutkan bacaan apa saja yang pernah kamu baca!. Guru memotivasi siswa yang berkaitan dengan materi pembelajaran. Selanjutnya guru menuliskan materi pembelajaran di papan tulis. Selanjutnya guru menyampaikan tujuan pembelajaran, yaitu siswa dapat membaca teks bacaan dengan lafal dan intonasi yang tepat. Setelah itu guru menyampaikan langkah-langkah pembelajaran yang akan dilaksanakan.

Kegiatan Inti

Tahap eksplorasi

Selanjutnya guru menunjukkan media kartu bergambar kepada siswa, lalu guru menjelaskan kepada siswa cara menggunakan media kartu bergambar yang akan digunakan. Guru memberikan contoh menggunakan media kartu bergambar, yaitu dengan mengamati gambar yang terdapat pada kartu bergambar, kartu bergambar yang digunakan sebagai contoh adalah "Wisata Ke Kebun Binatang" dalam gambar tersebut mengambarkan keluarga Tina sedang berkunjung ke kebun binatang, lalu guru membaca teks bacaan yang terdapat pada kartu dengan lafal dan intonasi yang tepat.

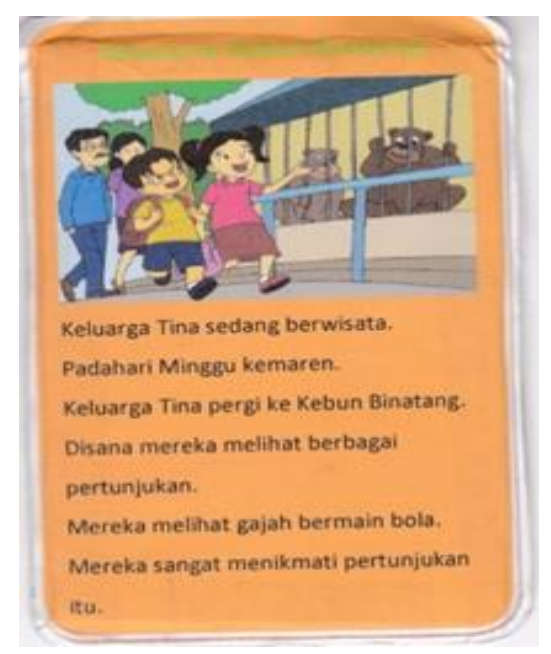

Gambar 3. Wisata Ke Kebun Binatang 
Sementara itu siswa memperhatikan guru dalam menggunakan kartu bergambar. Selanjutnya guru meminta salah satu siswa maju ke depan untuk membaca teks bacaan yang terdapat pada kartu bergambar.

\section{Tahap Elaborasi}

Pada tahap ini siswa dibagi oleh guru kedalam beberapa kelompok, setiap kelompok terdiri dari dua orang. Kelompok tersebut dibentuk sesuai dengan teman sebangku. Guru kemudian membagikan LKS dan kartu bergambar kepada masing-masing kelompok. Siswa memperhatikan guru dalam mejelaskan cara mengerjakan LKS yaitu dengan cara siswa diminta untuk memperhatikan kartu bergambar yang dimiliki siswa, kemudian siswa diminta untuk membaca teks yang terdapat pada kartu tersebut. Guru membimbing siswa dalam menggunakan kartu bergambar.

\section{Tahap Konfirmasi}

Kemudian guru setiap masing-masing kelompok untuk maju ke depan kelas untuk membacakan teks bacaan yang terdapat pada kartu bergambar secara bergantian dengan lafal yang tepat. Sedangkan kelompok lain memperhatikan kelompok yang maju ke depan kelas ketika membaca kartu bergambar.

\section{Kegiatan Akhir}

Pada akhir pembelajaran guru bersama siswa membuat hasil kesimpulan pembelajaran, dan menyampaikan materi untuk pertemuan selanjutnya. Kemudian guru menutup pembelajaran dengan berdoa.

\section{Ulangan Harian Siklus II}

Ulangan Harian II ini berbentuk sebuah teks pendek sederhana. Guru meminta setiap siswa maju kedepan untuk membaca teks pendek tersebut. . Guru juga melakukan penilai hasil bacaan siswa. Waktu yang digunakan untuk melaksanakan UH II ini selama 70 menit. Materi yang termasuk dalam UH ini adalah materi pertemuan pertama dan kedua pada siklus II. Saat siswa sedang membaca didepan kelas, guru meminta siswa lain untuk latihan membaca dengan membaca buku cetak Bahasa Indonesia.

\section{Refleksi Siklus II}

Berdasarkan hasil pengamatan siklus II yang dilakukan sebanyak dua kali pertemuan, penggunaan media kartu bergambar ini sudah terlaksana dengan sangat baik. Hal ini dapat dilihat dari hasil belajar siswa dan nilai Ulangan Harian I dan II siswa mengalami peningkatan. Peneliti juga dapat mengkondisikan kelas dengansangat baik, siswa tidak lagi ribut dalam proses pembelajaran. Dengan adanya peningkatan dari hasil kemampuan membaca siswa yang telah dilaksanakan, maka penelitian ini telah dinyatakan tuntas.

\section{Hasil Penelitian}

Hasil penelitian yang diperoleh terdiri dari lembar aktivitas guru, lembar aktivitas siswa, dan hasil kemampuan membaca siswa ketika menggunakan media kartu bergambar.

\section{Aktivitas Guru \\ Lembar aktivitas guru selama proses mengajar menggunakan media kartu bergambar diamati oleh observer. Hasil aktivitas guru pada siklus I dan siklus II dapat dilihat pada tabel berikut}

Tabel 4. Persentase Aktivitas Guru pada Setiap Pertemuan Siklus I dan II.

\begin{tabular}{clccc}
\hline Siklus & Pertemuan & Jumlah & Persentase & Kategori \\
\hline I & Pertemuan 1 & 17 & $70,83 \%$ & Baik \\
& Pertemuan 2 & 18 & $75 \%$ & Baik \\
II & Pertemuan 1 & 20 & $83,33 \%$ & Amat Baik \\
& Pertemuan 2 & 21 & $87,5 \%$ & Amat Baik \\
\hline
\end{tabular}

Berdasarkan tabel di atas dapat diketahui aktivitas guru pada setiap pertemuan dalam setiap siklus. Pada siklus I pertemuan pertama aktivitas guru diperoleh skor 17 dengan presentase $70,83 \%$ dengan kategori baik. Pada siklus II pertemuan kedua aktivitas guru telah berjalan lebih baik dengan skor 18 dengan persentase $75 \%$ dengan kategori baik. 
Aktivitas guru pada siklus II pertemuan pertama proses pembelajaran sudah berjalan dengan sangat baik dengan skor yang diperoleh yaitu 20 dengan persentase 83,33\% dengan kategori amat baik. Pada pertemuan kedua siklus II aktivitas guru telah berjalan sangat lancar dengan skor 21 dengan persentase $87,5 \%$ dengan kategori amat baik.

\section{Aktivitas Siswa}

Hasil aktivitas siswa pada siklus I dan Siklus II dapat dilihat pada tabel berikut ini:

Tabel 5. Persentase Aktivitas Siswa pada Setiap Pertemuan Siklus I dan II.

\begin{tabular}{clccc}
\hline Siklus & Pertemuan & Jumlah & Persentase & Kategori \\
\hline I & Pertemuan 1 & 17 & $70,83 \%$ & Baik \\
& Pertemuan 2 & 19 & $79,17 \%$ & Baik \\
II & Pertemuan 1 & 21 & $87,5 \%$ & Amat Baik \\
& Pertemuan 2 & 22 & $91,67 \%$ & Amat Baik \\
\hline
\end{tabular}

Berdasarkan tabel 6 dapat dijelaskan aktivitas siswa pada siklus I pertemuan pertama memiliki skor 17 dengan presentase 70,83\% dengan kategori baik. Pada pertemuan kedua siklus I aktivitas siswa dalam proses pembelajaran telah berjalan dengan baik dengan skor 19 dengan persentase $79,17 \%$ dengan kategori baik. Pada siklus II pertemuan pertama aktivitas siswa telah berjalan dengan sangat baik dengan skor 21 dengan persentase $87,5 \%$ dengan kategori amat baik. Kemudian pada pertemuan kedua siklus II aktivitas siswa telah berjalan dengan lancar dengan skor yang diperoleh adalah 22 dengan persentase 91,67\% dengan kategori amat baik.

\section{Hasil Kemampuan Membaca Siswa}

Hasil peningkatan kemampuan membaca siswa setelah menggunakan kartu bergambar dapat dilihat pada hasil kemampuan membaca pada ulangan siklus I dan II.

\section{Hasil Kemampuan Membaca Siswa Siklus I}

Hasil kemampuan membaca siswa setelah menggunakan kartu bergambar dapat dilihat hasilnya sesuai dengan kategori kemampuan membaca pada tabel dibawah ini:

Tabel 6. Kategori Hasil Kemampuan Membaca Membaca Siswa pada Ulangan Harian Siklus I.

\begin{tabular}{cccc}
\hline Interval & Kategori & Jumlah Siswa & Persentase \\
\hline $80-100$ & Sangat Baik & 4 & $16,67 \%$ \\
$70-79$ & Baik & 9 & $37,5 \%$ \\
$60-69$ & Cukup & 8 & $33,33 \%$ \\
$50-59$ & Kurang & 3 & $12,5 \%$ \\
$0-49$ & Kurang sekali & - & - \\
\hline
\end{tabular}

Dari tabel di atas dapat dilihat bahwa hasil kemampuan membaca siswa dengan menggunakan kartu bergambar melalui ulangan harian siklus I di peroleh nilai dengan kategori sangat baik berjumlah 4 orang siswa dengan presentase $16,67 \%$, selanjutnya dengan kategori baik sebanyak 9 orang siswa dengan presentase $37,5 \%$, kemudian yang memperoleh nilai dengan kategori cukup berjumlah 8 orang siswa dengan prsentase $33,33 \%$, dan siswa yang memperoleh nilai dengan kategori kurang berjumlah 3 orang siswa dengan presentase $12,5 \%$. Sedangkan untuk siswa yang memperoleh nilai dengan kategori kurang sekali yaitu tidak ada satu siswa pun yang memperoleh nilai dengan kategori kurang sekali.

Hasil Kemampuan Membaca Siswa Siklus II Hasil kemampuan membaca siswa siklus II dapat dilihat pada tabel berikut: 


\section{PRIMARY : JURNAL PENDIDIKAN GURU SEKOLAH DASAR \\ Volume 8 Nomor 2 Oktober 2019 \\ DOI : http://dx.doi.org/10.33578/jpfkip.v8i1.7628 \\ ISSN : 2303-1514 | E-ISSN : 2598-5949 \\ https://primary.ejournal.unri.ac.id/index.php/JPFKIP}

Tabel 7. Kategori Hasil Kemampuan Membaca Membaca Siswa pada Ulangan Harian Siklus II.

\begin{tabular}{cccc}
\hline Interval & Kategori & Jumlah Siswa & Persentase \\
\hline $80-100$ & Sangat Baik & 13 & $54,17 \%$ \\
$70-79$ & Baik & 8 & $33,33 \%$ \\
$60-69$ & Cukup & 3 & $12,5 \%$ \\
$50-59$ & Kurang & - & - \\
$0-49$ & Kurang sekali & - & - \\
\hline
\end{tabular}

Dari di atas dapat dilihat bahwa hasil kemampuan membaca siswa dengan menggunakan kartu bergambar mengalami peningkatan pada ulangan harian siklus II. Dimana di peroleh nilai dengan kategori sangat baik berjumlah 13 orang siswa dengan presentase $54,17 \%$, selanjutnya dengan kategori baik sebanyak 8 orang siswa dengan presentase $33,33 \%$, kemudian yang memperoleh nilai dengan kategori cukup berjumlah 3 orang siswa dengan presentase 12,5\%, dan tidak ada satupun siswa yang memperoleh nilai dengan kategori kurang dan kurang sekali.

\section{Peningkatan Hasil Kemampuan Membaca Siswa}

Setelah melaksanakan tindakan dapat dilihat adanya peningkatan kemampuan membaca siswa sebelum dan sesudah tindakan. Hal ini dapat dilihat dari nilai rata-rata hasil kemampuan membaca siswa dari skor dasar, ulangan harian siklus I, dan ulangan harian siklus II pada tabel dibawah ini:

Tabel 8. Perbandingan Rata-Rata Hasil Kemampuan Membaca Siswa Dari Skor Dasar Siklus I dan Siklus II.

\begin{tabular}{cccccc}
\hline No. & Data & Jumlah siswa & Rata-rata & \multicolumn{2}{c}{ Peningkatan } \\
\cline { 5 - 6 } & & & & SD- Siklus I & SD- Siklus II \\
\hline 1. & SD & 24 & 63,75 & & \\
2. & UH I & 24 & 73,88 & $15,89 \%$ & \\
3. & UH II & 24 & 83,96 & & $31,70 \%$ \\
\hline
\end{tabular}

Dari tabel di atas dapat dilihat bahwa penggunaan media kartu bergambar dapat meningkatkan memampuan membaca siswa. Sebelum menggunakan media kartu bergambar, kemampuan membaca siswa dapat dilihat dari nilai rata-rata skor dasar adalah 63,75. Namun setelah mengunakan media kartu bergambar kemampuan membaca siswa meningkat dari skor dasar ke ulangan harian siklus I yaitu dari 63,75 meningkat sebanyak $15,89 \%$ menjadi 73,88 . Sedangkan pada ulangan harian siklus II terjadi peningkatan kemampuan membaca dari skor dasar ke ulangan harian siklus II yaitu yaitu 63,75 meningkat sebanyak $31,70 \%$ menjadi 83,96.

\section{Pembahasan}

Menurut pendapat Orthied (2013) tantangan terbesar seorang guru sekolah dasar adalah menggunakan stategi pembelajaran dalam proses belajar mengajar. Penggunaan media kartu bergambar merupakan suatu strategi pembelajaran yang dapat digunakan dalam proses belajar mengajar. Dengan menggunakan media kartu bergambar guru telah membuat proses pembelajaran menjadi lebih bermakna. Hal ini dapat dilihat berdasarkan hasil penelitian yang telah telah dilaksanakan bahwa dengan menggunakan media kartu bergambar dapat meningkatkan kemampuan membaca siswa dalam proses pembelajaran

Data aktivitas guru dengan menggunakan media kartu bergambar mengalami penigkatan pada setiap pertemuan. Pada pertemuan pertama siklus I data hasil observasi aktivitas guru dengan presentase 70,83\% dengan kategori baik. Kemudian meningkat pada pertemuan kedua siklus 
I menjadi $75 \%$ dengan kategori baik. Meskipun siklus I berjalan dengan baik tetapi masih ada beberapa kelemahan dalam aktivitas guru yaitu: guru kurang mampu melakukan dalam menarik perhatian siswa, guru kurang mampu menguasai kelas sehingga terdapat beberapa siswa ribut dan tidak memperhatikan guru ketika proses pembelajaran berlangsung, guru kurang mampu dalam menyampaikan materi pelajaran sehingga banyak siswa yang belum mampu menyuasai materi pembelajaran, guru kurang mampu memberikan motivasi kepada siswa sehingga siswa kurang bersemangat ketika melakukan pembelajaran.

Pada pertemuan pertama siklus II data aktivitas guru mengalami peningkatan dengan presentase $83,33 \%$ dengan kategori baik, kemudian pada pertemuan kedua siklus II aktivitas guru kembali mengalami peningkatan menjadi $87,5 \%$ dengan kategori amat baik. Hal ini disebabkan karena pada siklus II guru sudah mulai terbiasa dalam proses pembelajaran sehingga siswa lebih aktif dalam proses pembelajaran.

Begitu pula dengan aktivitas siswa ketika menggunakan media kartu bergambar juga mengalami peningkatan. Pada pertemuan pertama siklus I memiliki persentase $70,83 \%$ dengan kategori baik. Pada pertemuan kedua siklus I mengalami peningkatan $\%$ menjadi $79,17 \%$ dengan kategori baik. Pada siklus I aktivitas siswa dapat dikatakan baik, meskipun terdapat beberapa anak yang masih ribut di dalam kelas, siswa kurang semangat ketika melakukan pembelajaran, ketika tugas kelompok banyak siswa yang tidak ikut berpartisipasi asyik pada kartu bergambar yang dimiliki.

Kemudian pada siklus II mengalami peningkatan kembali, pada pertemuan pertama siklus II aktivitas siswa memiliki presentase $87,5 \%$ dengan kategori amat baik, dan pada pertemuan kedua siklus II aktivitas siswa mengalami peningkatan dengan presentase $91,67 \%$ dengan kategori amat baik. Hal ini disebabkan karena seluruh siswa sudah mulai aktif dalam mengikuti pembelajaran. Terjadinya aktivitas guru karena adanya perbaikan dalam proses pembelajaran. Aktivitas guru mengalami peningkatan pada setiap siklusnya karena guru dan siswa sangat berjalan lancar sehingga hasil belajarpun meningkat.

Kemampuan membaca siswa dapat dilihat dari hasil penilaian ulangan harian pada siklus I dan II. Dibandingkan sebelum menggunakan media kartu bergambar nilai ulangan harian setelah menggunakan media kartu bergambar mengalami peningkatan. Skor dasar kemampuan membaca siswa sebelum menggunakan media kartu bergambar yaitu 63,75 dengan kategori baik. Pada siklus I kemampuan membaca siswa meningkat sebanyak $15,89 \%$ dengan nilai rata-rata 73,88 dengan kategori sangat baik. Pada ulangan harian siklus I dari 24 siswa, siswa yang memperoleh kategori sangat baik dalam membaca berjumlah 5 siswa dengan presentase $20,83 \%$, dengan 4 siswa memiliki jumlah skor 89 dan 1 siswa memiliki skor 100. Kemudian siswa yang memiliki kategori baik berjumlah 8 siswa dengan presentase $33,33 \%$ siswa tersebut memiliki skor 78, untuk siswa dengan kategori cukup berjumlah 7 siswa dengan presentase $29,17 \%$ siswa tersebut memiliki skor 67. Sedangkan siswa yang memiliki kategori kurang berjumlah 4 siswa dengan presentase $16,67 \%$ siswa tersebut memiliki skor berjumlah 56, dalam ulangan harian siklus I ini tidak terdapat siswa yang memiliki kemampuan membaca dengan kategori kurang sekali.

Kemudian pada siklus II mengalami peningkatan sebesar $31,70 \%$ dari nilai rata-rata skor dasar 63,75 meningkat menjadi 83,96 dengan kategori sangat baik. Pada siklus II kemampuan membaca siswa menggunakan media kartu bergambar kembali mengalami peningkatan, siswa yang memperoleh kategori sangat baik berjumlah 13 siswa dengan presentase $54,17 \%$ dengan 10 siswa memiliki skor 89 dan 5 siswa memiliki skor 100. Selanjutnya siswa yang memperoleh baik berjumlah 8 siswa dengan presentase $33,33 \%$ skor yang dimiliki berjumlah 78. Untuk siswa yang memperoleh kategori cukup berjumlah 3 siswa dengan kategori $12,5 \%$ skor yang dimiliki siswa tersebut adalah 67. Pada ulangan harian siklus II ini tidak terdapat siswa yang memiliki kemampuan membaca kurang dan kurang sekali.

Berdasarkan penjelasan di atas, maka sesuai dengan Suhrianati (2016) tentang media pembelajaran kartu bergambar dapat meningkatkan aktivitas guru, siswa dan kemampuan membaca permulaan dalam pelaksanaan membaca 


\section{PRIMARY : JURNAL PENDIDIKAN GURU SEKOLAH DASAR \\ Volume 8 Nomor 2 Oktober 2019 \\ DOI : http://dx.doi.org/10.33578/jpfkip.v8i1.7628 \\ ISSN : 2303-1514 | E-ISSN : 2598-5949 \\ https://primary.ejournal.unri.ac.id/index.php/JPFKIP}

permulaan. Kartu bergambar hendaknya lebih divariasikan karena dapat membuat siswa lebih

\section{SIMPULAN DAN REKOMENDASI}

Berdasarkan hasil analisis dan pembahasan yang telah dilaksanakan dapat disimpulkan bahwa penggunaan media kartu bergambar dapat meningkatkan kemampuan membaca siswa kelas II SDN 067 Pekanbaru. Hal ini dapat dibuktikan oleh:

1. Peningkatan kemampuan membaca siswa kelas II SDN 067 Pekanbaru yaitu dari skor dasar 63,75 meningkat pada siklus I menjadi 73,88 dengan persentase $15,89 \%$, kemudian pada siklus II kembali mengalami peningkatan menjadi 83,96 dengan persentase $31,70 \%$.

2. Aktivitas guru mengalami peningkatan yaitu pada siklus I pertemuan pertama memiliki persentasi $70,83 \%$ meningkat pada pertemuan kedua siklus I menjadi 75\%. Pada siklus II pertemuan pertama meningkat menjadi $83,33 \%$,

\section{DAFTAR PUSTAKA}

Aqib, Z. (2011). Penelitian Tindakan Kelas untuk Guru SMP,SMA,SMK. Bandung: CV. Yrama Widya.

Aqib, Z. (2016). Penelitian Tindakan Kelas untuk Guru SD, SLB dan TK. Bandung: CV Yrama Widya.

Arikunto, S. (2015). Penelitian Tindakan Kelas. Jakarta: Bumi Aksara.

Arsyad, A. (2011). Media Pembelajaran. Jakarta: Rajawali Pers.

Aryani, S., dkk. (2012). Peningkatan Keterampilan Membaca Pemahaman Melalui Srategi Know-Want-Learned (KWL) pada Siswa IV A SDN Sekaran 01 Semarang. Joyful Learning Journal, 1(1), 62-70.

B, H, dkk. (2012). Menjadi Peneliti PTK Yang Profesional. Jakarta: PT Bumi Aksara.

Fadillah, M. (2014). Desain Penelitian PAUD. Jogjakarta: Ar-Ruzz Media.

Habibi, N. (2017). The Use Of Flashcard In Improving Vocabulary Mastery Of Students Witd Disability. Inklus: Journal of Disability Studies, 4(2), 198-216. rajin belajar membaca sehingga kemampuan membaca permulaan dapat terus meningkat.

pada pertemuan kedua siklus II meningkat lagi menjadi $87,5 \%$. Aktivitas siswa mengalami peningkatan yaitu pada siklus I pertemuan pertama memiliki persentasi $70,83 \%$ meningkat pada pertemuan kedua siklus I menjadi 79,17\%. Pada siklus II pertemuan pertama meningkat menjadi $87,5 \%$, pada pertemuan kedua siklus II meningkat lagi menjadi 91,67\%.

Berdasarkan hasil kesimpulan diatas, peneliti rekomendasikan sebagai berikut: 1) Media kartu bergambar dapat dijadikan sebagai salah satu media pembelajaran yang dapat diterapkan oleh guru untuk meningkatkan kemampuan membaca siswa; 2) Penggunaan media kartu bergambar dapat meningkatkan kualitas aktivitas guru dan siswa dalam proses pembelajaran terutama dalam meningkatkan kemampuan membaca.

Hermida, J. (2009). The Inprtance of Teaching Academic Reading Skills in First-Year University Courses. The International Journal of Researdh and Review, 3. (Online).

https://www.researchgate.net/publication/2 28176003 The Importance of Teaching Academic Reading Skills In First-

Indriana, D. (2011). Ragam Alat Bantu Media Pengajaran. Jogjakarta: Diva Perss.

Irdawati, dkk. (2017). Meningkatkan Kemampuan Membaca Permulaan dengan Menggunakan Media Gambar Kelas 1 di Min Boul. Jurnal Kreatif Tadukalo, 5(4), 1-14.

Kavani, R., dkk. (2016). The Effect of Strategybased Instruction on Motivation, Selfregulated Leaning, and Reading Comprehension Ability of Iranian ELF Learning. Jurnal Cogent Education, 1-17. https://www.tandfonline.com/doi/full/10.1 080/2331186X.2018.1556196.

Langi, A., dkk. (2016). Peningkatan Kemampuan Membaca dan Menulis Dengan 


\section{PRIMARY : JURNAL PENDIDIKAN GURU SEKOLAH DASAR \\ Volume 8 Nomor 2 Oktober 2019 \\ DOI : http://dx.doi.org/10.33578/jpfkip.v8i1.7628 \\ ISSN : 2303-1514 | E-ISSN : 2598-5949 \\ https://primary.ejournal.unri.ac.id/index.php/JPFKIP}

Menggunakan Kartu Huruf di Kelas I SDN

2 Wonbo. Jurnal Kreatif Tadukalo, 4(8), $88-102$.

Nurgraheni, A. (2012). Pengajaran Bahasa Indonesia Berbasis Karakter. Pustaka.

Ortlieb, E. (2013). Using Anticipatory Reading Guides to Improve Elementary Students'Comprehension. Internasional Journal of Instruction, 6(2).

Purwanto, N. (2013). Prinsip-Prinsip dan Teknik Evaluasi Pengajaran. Bandung: PT Remaja Rosdakarya.

Sismulyasih, N. (2018). Peningkatan Kemampuan Membaca dan Menulis Permulaan Menggunakan Strategi Bengkal Literasi Pada Siswa SD. Jurnal Primary 7(1), 6874.

Suhrianati. 2016). Peningkatan Aktivitas dan Kemampuan Membaca Permulaan Melalui Media Pembelajaran Kartu Bergambar Siswa Kelas Satu. Jurnal Sagacious, 3(1). (Online).

http://eprints.ums.ac.id/20090/18/NASKA H_PUBLIKASI.pdf.

W, Solchan T., dkk. (2014). Pendidikan Bahasa Indonesia di SD. Banten: Universitas Terbuka

Zuchdi, D., dkk. (1996). Pendidikan Bahasa dan Sastra di Kelas Rendah. Jakarta: Depdikbud. 